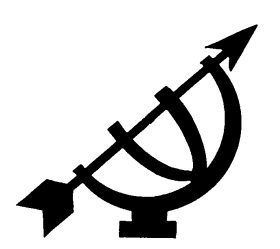

\title{
The influence of the pre-scientific and scientific belief system of both counsellor and client on the success of the narrative process
}

Willie Luyt

Department of Philosophy

Vaal Triangle campus

North-West University

VANDERBIJLPARK

E-mail: filwjal@puknet.puk.ac.za
P.J.M. van Niekerk

School of Sociology

Vaal Triangle campus

North-West University

VANDERBIJLPARK

pierre.vanniekerk@nwu.ac.za

\begin{abstract}
The influence of the pre-scientific and scientific belief system of both counsellor and client on the success of the narrative process
\end{abstract}

The aim of this article is to investigate to what extent the belief system of both counsellor and client plays a role in counselling. It is generally accepted that beliefs play a central role in the life of all people. This article applies this notion, as described by, among others, Wright, Watson and Bell (1986), to the field of pastoral care and more specifically to the narrative approach within it. The narrative approach is an important instrument that helps people to understand how their life stories have been shaped by their beliefs about themselves. Throughout the article the researcher attempts to indicate how the counsellor, client and counselling process are influenced by their respective scientific and pre-scientific roots and development, as well as by their system of belief in general.

\section{Opsomming}

Die invloed van die voorwetenskaplike en wetenskaplike oortuigingstelsel van sowel die berader as die kliënt op die sukses van die narratiewe proses

Hierdie artikel het ten doel om vas te stel in watter mate die oortuigingstelsel van die berader en die kliënt 'n rol in berading speel. Dit word algemeen aanvaar dat oortuigings 'n sentrale rol 
in mense se lewe speel. Hierdie artikel pas die voorafgaande idee, soos beskryf deur onder andere Wright, Watson en Bell (1986), toe op die veld van pastorale berading, en meer spesifiek die narratiewe benadering. Die narratiewe benadering is 'n belangrike instrument wat mense in staat stel om te verstaan hoe hulle lewensverhale gevorm word deur hulle oortuigings rakende hulself. Die navorser wend deurentyd 'n poging aan om aan te dui hoe die berader, die kliënt en die beradingsproses deur hulle wetenskaplike en voorwetenskaplike wortels en ontwikkeling, asook deur hulle oortuigingstelsel in die algemeen, beïnvloed word.

\section{Introduction}

Philosophical points of departure are often only implicitly presented in a theory. Despite the fact that they are not made explicit, these ideas still have an influence on the theory as well as the practice. Some philosophical points of departure are made explicit in Dwivedi and Gardner's (1997:19-20) explanation of the narrative approach to counselling. According to these authors life is a continuous process of organising experiences. People have a strong longing for order and sense, but live in a world that might not possess any. Because they do not have a direct knowledge of the world, their knowing requires that they ascribe meaning to their experiences, which then become comprehensible when seen in a historical sequence of beginning, middle and end. The lived experiences and events are therefore turned into "stories" in order for people to be able to express themselves and make sense of their lives. They "story" their experiences, and through this process of "storying" they derive meaning.

In the above explanation of narrative theory, the focus on individual interpretation suggests that this theory moves away from the modernist theory of counselling, towards the more open themes of postmodernism. The difference between a modernist and postmodernist approach to counselling can be located in their divergent views of the individual, his/her relation to society, and the description of the problem that led to the counselling process. In general, the modernist approach relies on "the power of science and the knowledge of objective experts who supposedly possess the truth about a reality which is out there ..." (Becvar \& Becvar, 1996:87). The modernist approach is based on the belief that it is moving towards a greater good through the use of technological advances. Becvar and Becvar (1996:87) make an interesting statement consistent with the latter point: "... the role of the therapist and social 
scientist has been that of the social engineer". The modernist theory of counselling also departs from the systems theory by saying that regardless of whether a system is a human body or a family, it is organised in a particular manner with boundaries that are more or less open, depending on the amount and type of feedback it receives (Gladding, 1998:74). Therefore there is no distance between the person and the problem, for example, "He is an alcoholic."

Postmodernism, however, questions and undermines several aspects of modernism, such as the possibility of objective knowledge and the absolute truth. Becvar and Becvar (1996:87-88) state that postmodern theory introduces certain changes: "... ours is a reality that is inevitably subjective ... we do indeed dwell in a multiverse which is constructed through the act of observation. Facts are being replaced by perspectives ...". In the narrative approach, for example, one would ask a person to tell one more about his/her story or lived experiences and explore why he/she is being dominated by alcohol, and together seek unique outcomes and a new alternative story.

In the narrative-therapy process, the counsellor and client's prescientific and scientific belief systems play a role, as well as the philosophical points of departure that are being used in the process of counselling. The following is an in-depth discussion of the definition, role and influence of our pre-scientific and scientific belief systems.

\section{Pre-scientific belief systems}

Wolters (1985:2-4) states that a pre-scientific belief system may be regarded as a summary of what he calls a worldview: "the comprehensive framework of one's basic beliefs about things". All individuals have a belief system that consists of their knowledge and convictions regarding matters such as God, relationships, society and structures within society - marriage, family, the church, etcetera. According to Van der Walt (1999:47) our faith commitment determines how we perceive and experience our reality, and therefore it may be regarded as an individual's most fundamental conviction. Walsh and Middleton (1984:34-35) add that "our ultimate faith commitment sets the contours of our world view". According to them, our faith commitment may determine how we perceive things, by means of the answers we give to the following questions: 
- Who am I?

- Where am I?

- What is wrong?

- What is the solution to the latter problem?

Each person's life story provides, both consciously and unconsciously, answers to these four questions. In order for the counselling session to be fulfilling, it is the counsellor's responsibility to listen carefully to the client's answers. Wright, Watson and Bell (1986:19) also highlight these significant aspects of a belief system. They state that beliefs are formed by our genetic make-up, our perceptions, and our interactions with others and our environment. These interactions challenge, confirm and refine our beliefs. Beliefs are the reason why and how we act or react to our environment. Beliefs influence our cognition, affect and behaviour. Schoeman $(2004: 173)$ states that "the pre-scientific domain of human experience encompasses our total existence. It is the 'world' in which we exist as totalities, in which we live, love, suffer, hope, struggle, believe, aspire, act and the like".

Since our belief systems are an integral part of who we are and how we perceive the world, it is necessary to discuss the influence of these belief systems on the counselling process. One way of accomplishing this is to construct a critical summary of the characteristics and role of a belief system.

\subsection{Characteristics of a pre-scientific belief system}

The following discussion is based on the work of four authors: Fowler (1991), B.J. van der Walt (1999), M.F. van der Walt (1998) and Wolters (1985). They have done in-depth research on the role belief systems play in people's lives. Following each characteristic, a short summary of its application to the counsellor and the client in the counselling context is given.

\subsubsection{Theocentric and cosmocentric belief systems}

Belief systems can be categorised into two groups, namely theocentric and cosmocentric. A theocentric belief system is based on one's faith commitments and has the Bible as its foundation. Therefore, the Word of God and not the word of people is at the centre of what one believes. A cosmocentric belief system is based on anything in creation, which becomes the centre of belief. 
These two categories need to be taken into account during the counselling session. For instance, the Christian counsellor should be aware that there are people who have a cosmocentric belief system, and they may pressurise Christians to conform to their "wordly" beliefs. When this occurs, people are often trapped in a dualistic lifecycle, because they only apply their faith commitments when in the context of their church communities. These dualistic life-cycles can cause relationship problems in other facets of life, such as work, family and society. Wolters (1985:10) states the following in this regard:

Each is understood to apply to only one delimited area of the universe of our experience ... Everything falling outside this delimited area is called the 'wordly', or 'secular'. All of these 'two-realm' theories are variations of a basically dualistic worldview, as opposed to the integral perspective of the reformational worldview.

\subsubsection{Belief systems are universal}

We shape our belief systems according to our experiences and the interpersonal contacts we make, from as early as birth. These belief systems influence our life drastically and involve all spectrums of life: "... Scripture speaks centrally to everything in our life and world, including technology and economics and science. Consequently, it is essential to relate the basic concepts of 'biblical theology' to our worldview ..." (Wolters, 1985:7). Our belief systems become universal because all people apply these belief systems to their lives. It seems impossible for people to separate themselves from their belief systems. Fowler (1991:51) highlights the latter point:

On the other side, however, is the encounter with a lawgoverned creation to which the human constructive activity is a response. This law-governed creation, being governed by God's creation - ordering Word as its law, is a universal creation order that all humans encounter as the same order. It is not a product of human knowing, but is a universal constant that is dependent on all human experience.

It becomes the counsellor's responsibility during the counselling session to guide the client in his/her understanding of why people say and do certain things. Therefore the counsellor should make the client aware of differing belief systems. The counsellor as well as the client should also be aware that everybody has a belief about various aspects in life, although it is sometimes not expressed explicitly. 


\subsubsection{Believing our belief systems speak the truth}

Our belief systems are not dull opinions, but are convictions. They are a strong force that functions actively in our life. We have accepted these beliefs as true and have made them our own. We also identify with these beliefs and therefore we are willing to protect them against negative criticism even in situations where our beliefs cause difficulties and suffering. The Greenpeace movement is a good example of this. The members of this movement are often willing to place their own life in danger to fight for nature conservation.

During the counselling session, the counsellor should be aware of the strong beliefs of his/her client. Even though these beliefs may not be acceptable within a particular society (such as, for example, beliefs about same-gender marriages) and the counsellor feels they need to be changed or adjusted, he/she should respect them for the sake of the quality of the session.

\subsubsection{Belief systems are emotionally charged}

When a person is convinced that his/her beliefs are the truth and identifies with them, he/she often becomes emotionally involved. This should not necessarily be regarded in a negative light, since it provides people with a sense of stability and endues them with feelings of satisfaction, happiness and peace. Van der Walt (1999:50) states the following in this regard: "Dit maak diep emosies by die mens wakker, maar gee ook groot stabiliteit, want dit verskaf 'n gevoel van geborgenheid, bevrediging, innerlike vreugde en vrede."

During a counselling session, the counsellor may become aware of the client's belief system especially when he/she has touched on a subject that causes the client to become defensive or emotional. Such subjects often include matters like religion, politics and sexual orientation.

\subsubsection{Belief systems resist change}

As already discussed, our belief systems are part of our convictions and are emotionally charged. Since we believe that they are the truth and defend them when others criticise their validity, it is understandable that we would resist anything that threatens our belief system's existence, such as change. In the counselling session, this resistance is usually increased when the counsellor 
and the client's belief systems clash and the client blocks any attempt to change or adjust.

\subsubsection{Faith commitments play a fundamental part in belief systems}

Our faith commitments are very important when we make decisions. They are usually the final standard upon which we base our decision-making process, and we formulate our arguments from this point of view. Van der Walt (1999:49) states that "... die geloofsoortuiging van 'n lewensvisie beïnvloed en bepaal jou redelike argumente. Anders gestel: 'n mens argumenteer vanuit 'n lewensvisie en nie daarnatoe nie". Our faith commitments play an integral role during the counselling session, because the Christian counsellor's belief system is shaped by and tested against the Bible. The counsellor will tend to formulate decisions and arguments based on "wrong" and "right". When a client approaches the counsellor, the counsellor should determine what the client's belief systems are, so that the counsellor can understand why the client argues the way he/she does.

\subsubsection{Belief systems are culturally bound}

Each community has certain traits that can be traced back to a shared belief system. These shared beliefs, such as norms and values, shape the community's lifestyle or culture: "Dit vind gewoonlik gestalte in simbole wat ' $n$ motiverende, inspirerende en samebindende krag het, ook vir 'n bepaalde groep of gemeenskap" (Van der Walt, 1999:50). Counsellors should be aware of South Africa's multicultural dynamics, since the belief system of each culture differs to some extent from another. For instance, within marriage counselling, a counsellor should be aware of the significance of lobola in the African culture. The following information regarding the concept of lobola is taken from the African Bride Magazine's (2003) website:

Lobola cements and seals forever the coming together of the families of the bride and the bridegroom. The common lobola for a wife is about ten or twelve head of cattle (or the equivalent monetary value), but a young woman of uncommon attractions, with good muscular frame, often commands from twenty to fifty animals (or the equivalent monetary value). The prospective bride's people find it more to their advantage to give their consent to the marriage at a ceremony or meeting where the first payment is made in advance of the real lobola. The first 
payment is known as vul'umlomo, that is to say 'please open your mouth and speak to us about lobola'.

In this context, the counsellor should be aware of problems associated with the payment of lobola. One of these is that often the bridegroom cannot pay the full amount of lobola before the time, and after negotiations by his family it is agreed that he can pay the outstanding lobola at a future date. This may lead to harassment by the bride's family, and the bride's father may take away their eldest daughter. Another traumatic consequence is that when the husband dies, the wife is reduced to a pitiable object. According to African Bride Magazine (2003) the widow "... continues to be the property of the husband's relatives ... She cannot return to her own people without the permission of her late husband's relatives". By gaining knowledge of culturally specific beliefs, the counsellor can provide the client with empathic listening and a deeper understanding of the situation.

\subsubsection{Belief systems provide direction}

According to Wolters (1985:4) our belief systems provide us with guidance, as a compass provides guidance when we are lost or in an unknown environment. Our belief systems become a driving force, since they drastically influence our thoughts and actions. Schoeman (2004:182) states that every human accepts his/her view of life as a normative framework that directs individual behaviour. He continues by stating that

acceptance of a definite view of life and the world is, therefore, a highly personal affair and is - undeniably - directly related ... to the deepest and most profound motivating forces behind human conduct, viz. the basic driving motives that undergird all human aspirations and actions.

There are three facets of the belief system's function as a driving force (providing us with direction) that demand attention.

- Firstly, a belief system influences our selection of data. We are susceptible to only selecting information that is in line with our convictions.

- Secondly, a belief system influences our interpretation of data. We tend to interpret words, actions, ideas and situations according to our convictions. 
- Thirdly, a belief system influences our behaviour. Our convictions are not passive; they influence our deeds and words.

Wolters (1985:4) makes the following comment: "Our worldview shapes ... the way we assess the events, issues, and structures of our civilization and our time. It allows us to 'place' or 'situate' the various phenomena that come into our purview." When a counsellor becomes aware of a belief system's dynamic nature and how it influences a person, he/she should give more attention to active listening - to him-/herself and the client - during a counselling session.

\section{Scientific belief systems}

All scientists, including counsellors, apply their scientific skills within the limits of their philosophical presuppositions, otherwise known as a scientific belief system. These presuppositions can be made explicit, but often they are accepted implicitly. Whether one uses them explicitly or implicitly, they remain a regulative and dynamic aspect of our thoughts. Botha's (1990:344) definition of what science is can be used as a good explanation of how a scientific belief system evolves: "Verantwoorde wetenskapsbeoefening verg die erkenning dat wetenskap 'n poging is om die reëlmatighede en wetmatighede kenmerkend van die verskynsels in die werklikheid, met hulp van teorieë te beskryf en te verklaar." This statement makes the importance of a counsellor's scientific belief system clear. The scientist, as well as the counsellor, has a certain theoretical belief system that has evolved through his/her participation and membership in the field of study. This theoretical belief system, which shapes his/her identity, becomes part of his/her scientific belief system.

Because of the important role they play in the narrative approach, it is essential to realise that there are significant differences between pre-scientific and scientific belief systems. The following is a short summary of these differences.

\subsection{The difference between a pre-scientific and a scientific belief system}

The pre-scientific belief system forms the basis of the scientific belief system. The counsellor can be classified as a scientist since he/she has scientifically researched information and knowledge in order to qualify as an expert in the field of counselling. According to Botha (1990:348-349) the majority of academics have a personal scientific 
belief system that has been shaped during the scientific process, and that they practise implicitly. The science of philosophy refers to a framework as a paradigm, and this paradigm carries the metaphysical, theoretical, conceptual and instrumental determination of the scientist and the particular scientific field. There are several theories within this scientific research process that influence and provide building blocks for the counsellor's scientific belief system. Schoeman (2004:174) elaborates this point by stating that "[a]ll our activities, including our pre-scientific endeavours, are rooted in this integral 'domain' of pre-scientific experiences". Popper (1979:345) explains the pre-scientific and scientific belief system as follows:

At every instant of our pre-scientific or scientific development we are living in the centre of what I usually call a horizon of expectations. By this I mean the sum total of our expectations, whether these are subconscious or conscious, or perhaps even explicitly stated in some language ... The various horizons of expectations differ, of course, not only in their being more or less conscious, but also in their content. Yet in all these cases the horizon of expectations plays the part of a frame of reference: only their setting in this frame confers meaning or significance on our experience, actions and observations.

Individuals' horizons of expectation differ, and therefore their prescientific and scientific belief systems will differ. Each counsellor develops his/her own style based on his/her personality, belief systems and scientific theories.

Ruggiero's (1999:1) explanation of the importance of our prescientific and scientific belief systems can enlighten the counsellor about the role of pre-scientific beliefs in the client's story:

The models people use to explain how the world works and the positions they hold on issues - such as capital punishment, welfare, day care for young children, and working mothers - are based on assumptions. When you identify assumptions, you uncover the hidden reasons that often serve as the bases for an orientation, opinion, or action.

The "models" Ruggiero are referring to point to our scientific belief system, which is strongly influenced by our pre-scientific belief system - or as Ruggiero calls it, our "assumptions". According to Ruggiero it can be difficult to identify these assumptions, since they are buried deep in our consciousness. The ability to identify these assumptions is crucial, because it allows for the differences between 
people's theoretical orientations within one discipline to be brought to the fore. Schoeman (2004:175) also supports the importance of a person's pre-scientific belief system:

Our pre-scientific, integral and essentially committed experience of reality provides the hypotheses from where all subsequent scientific explication of phenomena that are encountered, are launched.

There are also a number of theories in the social sciences that have contributed to the development of, and have had an important impact on, the practice of narrative counselling. These will subsequently be discussed.

\section{The systems theory}

The key concept within the systems theory can be defined in a single sentence: “ $\ldots$ a system is a set of elements standing in interaction" (Nichols \& Everette, 1986:69). According to Ludwig von Bertlanffy (Gladding, 1998:74), a biologist and the founder of the systems theory, the systems theory can be used to show how organisms flourish or die in relation to how open or closed they are to their environment. Gladding (1998:74) gives the following description of the systems theory and its relevance to systems such as families:

Each element in the system is affected by whatever happens to any other element. Thus the system is only as strong as its weakest part. Likewise the system is greater than the sum of its parts. Whether the system is a human body or a family, it is organized in a particular manner with boundaries that are more or less open. By viewing the family in this manner clinicians in the 1960's focused away from linear causability (direct and effect) and more on circular causability (the idea that events are related through a series of interacting loops or repeating cycles).

Since we are involved with one another on several levels, we are all seen as both subjects and objects. The truth is not separate from us, but is constructed through our perceptions, our understanding of the truth, and the meaning we assign to it. We are pro-active, meaning that we react and are actively involved in personal choices that lead to our destiny. We admit that our body and soul are inseparable, that we cannot ignore subjectivity, and that value-free science does not exist. It becomes evident from the above that the influence of pre- 
scientific and scientific belief systems during the counselling session cannot be ignored.

The systems theory is, however, still strongly rooted in a modernist mode of thinking and doing, since the position of the counsellor is regarded as that of an objective observer. Anderson and Goolishian (1988:374-375) describe the systems approach as a first wave of new ideas which moves in two directions:

The first direction appears to be an extension of the underlying assumptions of the traditional and prevailing paradigm in social sciences. This direction derives meaning and understanding from observing patterns of social organization such as structure and role.

The second direction in the family field:

$\ldots$ is based on the proposition that systems can be described as existing only in language and communicative action ... This position does not seek universal or normative social parameters in describing social organization. On the contrary ... social systems are a result of the continuing struggle towards understanding that occurs between interacting and communicating persons. Meaning and social systems are created in and through dialogue.

Anderson and Goolishian (1988:377) also emphasise that no human being lives in total isolation. Our lives are linked, and our interaction with others is based upon language. Language provides us with an opportunity to make contact and share our realities. In this sense, the systems theory moves closer to the social constructivist theory, in which narrative therapy finds its roots. It is evident that the communication process, or dialogue, between counsellor and client is an important concept in the systems theory. Knowledge of the systems theory may help to shape this communication process and add meaning to the counselling session.

\section{Constructivism}

Gergen (1985:266-275) makes the following comment about the development of constructivist epistemology:

Early theories emphasized knowledge as being the awareness of objects that exist independent of any subjects. According to this objectivist view, objects have intrinsic meaning, and knowledge is a reflection of a correspondence to reality. In this tradition, knowledge should represent a real world that is 
thought of as existing, separate and independent of the knower, and this knowledge should be considered true only if it correctly reflects that independent world. In contrast, the constructivist view argues that knowledge and reality do not have an objective or absolute value or, at least, that we have no way of knowing this reality.

Gergen's comment expresses the assumption that each individual has a unique way of knowing, and each of these unique ways of knowing should be accepted and adjusted to by others.

Menuchin (1991:48) explains the role and influence of constructivism within counselling. According to him, family therapists and counsellors have transformed the fascination of stories into a philosophical redefinition of therapy and the role of the therapist. Constructivists argue that therapy is nothing more than an exchange of stories between the therapist and the client. Menuchin (1991:48) also speaks of

... a time when many people feel helpless beneath the crushing weight of social calamity - poverty, drugs, environmental destruction, and perhaps it seems pointless for therapists to suggest they can change anything. But the power of the therapist does not disappear simply through renaming it something else.

Although constructivism has had certain positive consequences, it seems that it has not succeeded in developing an intervention that avoids "control" and an emphasis on "correction". Constructivism has merely shifted its focus away from power, allowing it to remain safely invisible and unexamined.

\section{Social constructivism}

Narratives such as hopelessness, helplessness and addiction can be seen as written by and perhaps dictated through social institutions. In order to help clients successfully with such personal narratives, more need to be done than just changing their narratives and life metaphors. Therefore a closer investigation of social constructivism would be of use.

Gergen (1985:266-275) explains the social constructivist's investigation as concerned mainly with the uncovering of the internal processes that people use to describe and explain the world in which they live. Kotze (1992:51) states that the social constructivist's theory attempts to highlight knowledge as the evolving process that 
finds its beginning through human beings. It is thus concerned with the status of knowledge as the social construction of humans, rather than an objective reflection of the external world, as believed by rationalists and empiricists. Knowledge and understanding of social constructs are realised in language. According to Roux (1996:6) knowledge and understanding are located within the social domain, and therefore it is impossible for knowledge and words to be true reflections of reality.

Social constructivism differs from the systems theory and constructivism in the sense that it takes the social aspects of human beings, rather than their biological aspects, as a point of departure. Each human being is seen as an individual, not isolated from social processes but actively living inside them. Being human is therefore constituted by the occurrence of communication and not merely by the fact that the human being is able to think. According to Kotze (1992:63-73) both communication and thinking are of importance. He believes that because the human being is a thinking organism, he/she imbues the social dimension with meaning. Our thoughts are a communication process; to think is to communicate with ourselves through language.

The characteristics of social constructivism add to the broader postmodern therapy movement. Dill (1995:184-186) describes these characteristics as follows:

a) Social constructivism questions the basic assumption of the positivist empirical approach, namely that knowledge has an objective basis. The social constructivist believes that people's knowledge and ideas concerning the world are social creations and therefore social processes play an important role in the interpretation of data.

b) Social constructivism highlights all possible means of communication. We live through our stories and create our lives through them. These stories are embedded within our cultural heritage, and through our interaction with one another a cultural internalisation takes place.

c) Social constructivism emphasises local knowledge gained through our communicative relationships existing within our cultures. Consequently a greater sensitivity to the immediate context and historical relevance develops. 
d) Human individuality is highlighted. The post-modern therapy movement does not allow the individual to be engulfed by cultural or social determinacy.

e) Social constructivism is set to discover and understand different interpretations, perspectives, stories and meanings. While the modernist approach aimed to discover consistent truths, post-modernism tries to discover several possible meanings in all situations.

Together with social constructivism, the narrative approach makes it possible for the counsellor and client to discover the variety of possible meanings in their life stories.

\section{The narrative approach}

Our narrative is our experiences that we interpret by telling stories. Narrative therapy focuses on bringing forth our internalised stories and changing negative experiences into positive, new stories. The narrative approach can also be regarded as a reaction against the earlier tendency of, for instance, psychology to classify people according to certain standard deviations from the norm. The latter approach is in line with the positivist way of thinking, which assumes that only knowledge gathered by means of a natural scientific method is valid. Instead of labelling and classifying people according to abnormalities and certain standard deviations from normality, the narrative approach attempts to emphasise an extended relationship with people. The core technique is to create a team consisting of counsellors and people united against the problem itself. The emphasis is on a victory over the perceived problem, and not on the problem itself; on the uniqueness of human beings, and not on their "deviations".

The following is a summary of the fundamental structure of the narrative approach as explained in Crafford and Kotze (1997:108110):

a) An acceptable name or metaphor is chosen for the problem to differentiate between the client and the problem. The client should choose this name him-/ herself.

b) The problem is personified so that the client is not seen as the problem. This helps to create a motivation for change. 
c) It is investigated how the problem has had an impact on the client and his/her family. The language chosen is non-deterministic, meaning the problem never 'creates', but rather 'invites' the families and persons involved to be influenced by it. The language emphasises the client's own responsibility.

d) Alternative stories, of times or situations when the client was not dominated by the problem, are discovered. These are referred to as unique outcomes and they create a new reality, which shows that change is possible and gives the client hope.

e) Reflecting on the meaning of these alternative moments, the client is empowered to re-author his/her story. New alternative stories are developed, which can lead to a new dominant story.

The process of narrative therapy has several advantages. These advantages are important since they set narrative therapy apart from other types of therapy. Besa (1994:309-325) formulates the following advantages:

a) People do not have to 'normalise' and compare themselves to other groups.

b) Narrative therapy does not require the diagnostic classification or specification of people.

c) Narrative therapy emphasises direct measurements such as behaviour and not indirect measurements such as questionnaires.

d) People can take part in problem identification, data collection, and potential data analysis.

e) Each intervention is suited to the specific and unique family.

f) The experimental design can be adapted during the counselling session.

The idea that individuals should not be classified according to a fixed set of rules that describe the "norm", is central. The focus is on direct means of measurement, such as the behaviour of a person, rather than on indirect means of measurement, such as questions. In Besa's study (1994:309-325) six families were treated using 
several narrative-therapy techniques. Besa stresses that narrative therapy is a reaction to the following view:

The traditional epistemology of 'normalcy' holds that there is one 'scientific' methodology to study human behaviour. Not surprisingly that method is founded on the 'normal' curve. The subject is then classified into certain standard deviations that specify his or her presumed degree of deviance (Besa, 1994:313).

In Besa's study, each intervention was tailored to the unique needs of a specific individual and his/her family.

Another benefit of the narrative approach is to be found in the principle that the individual is the expert regarding his/her own story and has the ability to discover a new alternative story. Zimmerman and Dickerson (1994:233-245) explain it as follows: "As people retell their stories in therapy, they often notice that they have already experienced participating in an alternative story." The counsellor only has to facilitate the client's discovery of these experiences.

Michael White and David Epston played a major role in the development of the narrative approach. According to Monk, Winslade and Crocket (1997:7) they were drawn to ideas about the subjective nature of reality and the nature of learning. To discover new information and to make it your own, you have to make use of a process of comparison - the ability to distinguish one set of events in time from another. Michael White noted that sometimes people adapt to the problems in their lives in such a way, that they are unaware of the influence of the problem on their lives and their own creative ability to reduce the impact of the problem. The counsellor can facilitate the process of discovering unique outcomes where the person has challenged the problem and discovered alternatives to the story.

According to McLead (1996:188), who also supports the narrative approach, a defining characteristic of being human, is telling stories. People tell stories to make sense of, and communicate and share their experiences of life. In the past, social scientists and psychologists have largely ignored the "storied" aspects of human behaviour in the search for variables and causal factors they considered to be theoretically important. Only in recent years has the trend of taking stories seriously emerged within the social sciences. 
While striving to make sense of the world, we need to organise our experiences into specific levels of time, so that we can have a clear picture of ourselves and the world around us. Specific experiences in the past and present, as well as the prediction of happenings in the future, are linked, and these shape our self-narrative. All stories have a beginning (history), middle (present) and end (future) and the knowledge we obtain when retelling our stories, has a certain positive and negative power over our lives. According to White and Epston (1990:22) knowledge and power are inseparable. Consequently they use these concepts as knowledge/power or power/knowledge: "A domain of knowledge is a domain of power, and a domain of power is a domain of knowledge."

\section{Conclusion}

Our thoughts and actions are influenced dynamically by the outcomes manifesting themselves in our belief system. Hence we cannot regard science as being practised neutrally. The client and counsellor add certain unique presuppositions at each counselling session and these presuppositions are embedded in each of their life- and worldviews, also known as their belief system. In this article, the author has focussed on the role and influence of both pre-scientific and scientific belief systems, not only in general, but also in a more focussed way, to suggest how these belief systems may be accommodated during a counselling session to ensure its success.

The various theoretical beliefs that form the basis of the narrative approach, namely the systems theory, constructivism and social constructivism, were briefly discussed in order to facilitate an understanding of the influences that have shaped the narrative approach. The narrative approach has opened the door to new experiences and developments within the science of counselling. The narrative approach suggests that when the counsellor's scientific belief system differs from the client's scientific belief system, it may influence the success of the counselling session. It is therefore the counsellor's responsibility to listen carefully and to acknowledge his/her own belief system as well as the client's belief system, and to help the client in understanding why each person involved in the counselling session thinks, feels and acts the way he/she does.

It is through knowledge that the counsellor's and client's prescientific and scientific belief systems can influence, and add to, the counselling session. The use of the narrative approach as an 
alternative to the conventional counselling process can only enhance the counselling session. Wright, Watson and Bell (1986:229-250) state the following:

Through our beliefs we develop our stance in the family, work and community - our stance in our interaction with others. Growth can only take place if beliefs are challenged and, if not useful, replaced. The co-constructive process engages the therapist and the client in a collaborative effort to uncover the client's strengths, 'unfreeze' their beliefs about themselves, and to nurture a sense of hope and growth e.g. a certain belief may emerge or does exist, such as 'I can't help it because I have a terrible temper'. This is a construction, and it may well be helpful to deconstruct it.

\section{List of references}

AFRICAN BRIDE MAGAZINE. 2003. Labola. http://www.africanbride.co.za/ab_ labola Date of access: 10 Feb. 2006.

ANDERSON, H. \& GOOLISHIAN, H.A. 1988. Human systems as linguistic systems: preliminary and evolving ideas about the implications for clinical theory. Family Process, 27:371-393.

BECVAR, D.S. \& BECVAR, R.J. 1996. Family therapy: a systematic integration. Boston: Allyn \& Bacon.

BESA, D. 1994. Evaluating narrative family therapy using single-system research designs. Research on Social Work Practice, 4(3):309-325.

BOTHA, M.E. 1990. Metateoretiese perspektiewe op die sosiale wetenskappe. Potchefstroom: IRS.

CRAFFORD, J.D. \& KOTZE, D.J. 1997. 'n Narratiewe pastorale terapie met depressiewe persone. Acta Theologica, 1:99-113.

DILL, I. 1995. 'n Basisteorie vir pastorale terapie in die lig van postmoderne epistomologie. Bloemfontein: UOVS. (Ph.D.-proefskrif.)

DWIVEDI, K.N. \& GARDNER, D. 1997. The therapeutic use of stories. London: Routledge.

FOWLER, S. 1991. A Christian voice among students and scholars. Potchefstroom: IRS.

GERGEN, K.J. 1985. Social constructivist movement in psychology. American Psychologist, 40:266-275.

GLADDING, S.T. 1998. Family therapy: theory and practice. Upper Saddle River. Merrill Prentice Hall.

KOTZE, D.J. 1992. Verantwoordelikheid as antropologiese essensie. Pretoria: UP. (Ph.D.-proefskrif.)

MCLEAD, J. 1996. Working with narratives. (In Bayne, R., Horton, I. \& Burnrose, J., eds. New directions in counselling. London: Routledge. p. 188-200.)

MENUCHIN, S. 1991. The seductions of constructivism. Family Therapy Networker, 15(5):47-50.

MONK, G., WINSLADE, J. \& CROCKET, K. 1997. Narrative therapy in practice: the archaeology of hope. San Francisco: Jossey Bass. 
NICHOLS, W.C. \& EVERETTE, C.A. 1986. Systemic family therapy: an integrated approach. New York: Guilford.

POPPER, K.R. 1979. Objective knowledge: an evolutionary approach. Oxford: Clarendon.

ROUX, J.P. 1996. Die ontwikkeling van 'n pastoraal-terapeutiese toerustingsprogram vir lidmate: 'n narratiewe benadering. Bloemfontein: UOVS. (Ph.D.-proefskrif.)

RUGGIERO, J. 1999. Thinking sociologically: a critical thinking activities manual. Boston: Allyn \& Bacon.

SCHOEMAN, P.G. 2004. Thoughts as to the location of ideology within the sphere of "belief systems". Tydskrif vir Christelike Wetenskap, 40(3/4):171197.

VAN DER WALT, B.J. 1999. Visie op die werklikheid: die bevrydende krag van 'n Christelike lewensbeskouing en filosofie. Potchefstroom: IRS.

VAN DER WALT, M.F. 1998. Handleiding: wetenskapsleerkursus vir nuwe dosente. Potchefstroom: $\mathrm{PU}$ vir $\mathrm{CHO}$.

WALSH, B.J. \& MIDDLETON, J.R. 1984. The transforming vision: shaping a Christian worldview. Downers Grove: InterVarsity.

WHITE, M. \& EPSTON, D. 1990. Narrative means to therapeutic ends. New York: Norton.

WOLTERS, A.M. 1985. Creation regained: Biblical bases for a reformational worldview. Grand Rapids: Eerdmans.

WRIGHT, L.M., WATSON, W.L. \& BELL, J.M. 1986. Beliefs: the heart of healing in families and illness. New York: Basic Books.

ZIMMERMAN, J.L. \& DICKERSON, V.C. 1994. If problems talked: narrative therapy in action. New York: The Guilford Press.

ZIMMERMAN, J.C. \& DICKERSON, V.C. 1994. Using a narrative metaphor: implications for theory and clinical practice. Family Process, 33:233-245.

\section{Key concepts:}

narrative approach: experiences interpreted through storytelling pre-scientific belief system: comprehensive framework scientific belief system: limits of philosophical presuppositions

\section{Kernbegrippe:}

narratiewe benadering: ervarings geïnterpreteer deur middel van die vertel van stories

voorwetenskaplike oortuigingstelsel: omvattende raamwerk wetenskaplike oortuigingstelsel: beperkinge van filosofiese voorveronderstellings 